\title{
PENGEMBANGAN LKS MATEMATIKA MENGGUNAKAN PENDEKATAN PROBLEM SOLVING PADA MATERI ARITMATIKA
}

\author{
Anggita Denia', Vera Mandailina², Syaharuddin ${ }^{3}$ \\ ${ }^{1}$ Pendidikan Matematika, Universitas Muhammadiyah Mataram, anggitadenia@gmail.com \\ ${ }^{2}$ Pendidikan Matematika, Universitas Muhammadiyah Mataram, vrmandailina@gmail.com \\ ${ }^{3}$ Pendidikan Matematika, Universitas Muhammadiyah Mataram, abialmusthafa@gmail.com
}

\begin{tabular}{l}
\hline \hline INFO ARTIKEL \\
\hline RiwayatArtikel: \\
Diterima : 12-03-2018 \\
Disetujui : 01-04-2018
\end{tabular}

Kata Kunci:

LKS Matematika

Problem Solving

\begin{abstract}
ABSTRAK
Abstrak: Penelitian ini bertujuan untuk menghasilkan LKS dengan menggunakan pendekatan pembelajaran Problem Solving pada materi aritmatika sosial untuk siswa SMP/MTs kelas VII. Selain itu, penelitian ini juga dilakukan untuk mengetahui kualitas kelayakan LKS yang dihasilkan berdasarkan aspek kevalidan, kepraktisan, dan keefektian. Jenis penelitian ini merupakan penelitian pengembangan dengan model pengembangan Borg And Gall yang terdiri dari 9 langkah yaitu (1) potensi dan masalah, (2) pengumpulan data, (3) desain produk, (4) validasi desain, (5) uji coba pemakaian, (6) revisi produk, (7) uji coba produk, (8) revisi desain, dan (9) revisi produk. Hasil penelitian menunjukkan kualitas produk yang dihasilkan berdasarkan (1) aspek kevalidan memenuhi kriteria valid dengan rata-rata total penilaian validator adalah 4,4. (2) Aspek kepraktisan memenuhi kriteria praktis dengan rata-rata total penilaian guru 4,4 dan angket respon siswa dengan persentase sebesar 93,33\% dan (3) aspek keefektifan memenuhi kriteria efektif dengan ketuntasan klasikal hasil belajar siswa yaitu $83,33 \%$.

Abstract: This study aims to produce LKS using Problem Solving learning approaches on social arithmetic material for students of SMP / MTs class VII. In addition, this study was also conducted to determine the quality of the feasibility of LKS generated based on aspects of validity, practicality, and effectiveness.

This type of research is a development research with Borg \& Gall development model consisting of 9 steps: (1) potential and problem, (2) data collection, (3) product design, (4) design validation, (5) (6) product revisions, (7) product tests, (8) design revisions, and (9) product revisions. The results showed that the quality of the products produced was based on (1) the validity aspect and met the valid criteria with the average total validator rating was 4.4. (2) practical aspect fulfill the practical criterion with the average total of teacher appraisal 4,4 and questionnaire of student response with percentage equal to 93,33\% and (3) effectiveness aspect fulfill the effective criteria with classical completeness of student learning result that is $83,33 \%$.
\end{abstract}

\section{A. LATAR BELAKANG}

Berdasarkan hasil observasi dan dokumentasi yang dilakukan di SMPN 2 Praya pada tanggal 13 februari 2017, dalam penerapan pembelajaran matematika guru sudah menggunakan metode yang beragam, antara lain ceramah, latihan dan diskusi. Bahan ajar yang digunakan guru masih berupa buku paket matematika. Namun metode tersebut belum dikembangkan secara optimal sehingga hasil belajar siswa belum maksimal.

Kriteria Ketuntasan Minimal (KKM) yang ditetapkan sekolah dan guru mata pelajaran matematika adalah 75 . Maka dapat dilihat dari tabel 1.1, siswa yang tidak tuntas pada mata pelajaran matematika di kelas VII.5 mencapai $84,85 \%$, VII.6 mencapai 97,06\% dan VII.7 mencapai $73,53 \%$. Dapat disimpulkan bahwa nilai ulangan harian semester genap siswa untuk mata pelajaran matematika masih banyak yang belum tuntas.

Rendahnya hasil belajar siswa diduga karena metode pembelajaran yang digunakan membuat peran guru lebih dominan sehingga siswa belum semua terlihat aktif dalam proses pembelajaran. Guru lebih banyak menyampaikan materi dengan metode ceramah, kemudian siswa diberikan soal latihan. Hal tersebut menyebabkan proses pembelajaran belum maksimal dalam memberikan kesempatan kepada siswa untuk berpikir kritis dan bertindak kreatif. Pembelajaran matematika yang seperti ini mengakibatkan siswa bekerja secara prosedural tanpa memahami konsep yang sebenarnya.

Selain itu, pembelajaran masih terpaku pada buku pelajaran dan kurang terkait dengan kehidupan siswa sehari-hari. Sehingga pembelajaran belum dapat dimaknai siswa untuk memecahkan masalah matematika secara realistis. Demikian juga dalam pembelajaran, siswa belum ditempatkan sebagai subjek belajar yang harus dibekali kemampuan bekerja sama, memiliki tanggung jawab atas tugasnya, serta kemampuan untuk menghargai orang lain.

Berdasarkan permasalahan di atas, guru harus mampu merancang pendekatan pembelajaran yang membuat siswa aktif melatih kemampuan berpikirnya 
dan memecahkan masalah matematika secara realistis. Hal ini memungkinkan siswa untuk memahami materi yang disampaikan guru secara lebih bermakna. Salah satu alternatif pendekatan pembelajaran yang dapat digunakan yaitu dengan menggunakan pendekatan Problem Solving dan rancangan LKS yang dibuat sesuai dengan langkah-langkah pada model Problem Solving. Fungsi dari LKS ini adalah untuk memudahkan pelaksanaan pengajaran kepada peserta didik dengan bahan ajar yang diringkas dan kaya tugas untuk berlatih dengan menggunakan model Problem Solving.

Hamiyah dan Jauhar (2014: 126) menyatakan bahwa Problem Solving merupakan penggunaan dalam kegiatan pembelajaran dengan jalan melatih siswa menghadapi berbagai masalah, baik masalah pribadi atau perorangan, maupun masalah kelompok untuk dipecahkan sendiri atau secara bersama-sama. Problem Solving merangsang pengembangan kemampuan berpikir siswa secara kreatif dan menyeluruh, karena dalam proses belajarnya siswa banyak melakukan proses runtut dengan melihat permasalahan dari berbagai segi dalam rangka mencapai pemecahannya.

Problem Solving memiliki kelebihan seperti yang diungkapkan Hamdani (2011: 84) antara lain: melatih siswa untuk mendesain suatu penemuan, berpikir dan bertindak kreatif, memecahkan masalah yang dihadapi secara realistis, serta merangsang perkembangan kemajuan berpikir siswa untuk menyelesaikan masalah yang dihadapi dengan tepat.

Penerapan pendekatan Problem Solving diharapkan membuat siswa lebih terampil dalam memecahkan masalah yang berkaitan dengan soal matematika. Problem Solving juga akan membantu pemahaman siswa karena berkaitan dengan kehidupan sehari-hari. Siswa juga dapat melatih kemampuan menghitung berdasarkan konsep matematika yang benar ketika menyelesaikan soal karena siswa belajar berdasarkan proses yang sistematis. Selain itu, siswa difasilitasi untuk bekerja sama dalam kelompok serta menghargai pendapat orang lain pada saat pemecahan masalah, serta menumbuhkan motivasi/minat untuk belajar. Jika halhal tersebut dapat terwujud, maka diharapkan metode Problem Solving dapat memberikan pengaruh yang signifikan terhadap hasi belajar matematika siswa.

Berdasarkan permasalah di atas, maka peneliti mengangkat judul penelitian " Pengembangan LKS Matematika menggunakan pendekatan Problem Solving Materi Aritmatika Sosial Kelas VII SMPN 2 Praya Tahun Pelajaran 2017/2018”.

\section{B. METODE PENELITIAN}

Model pengembangan yang digunakan dalam penelitian ini adalah Borg \& Gall dalam Sugiyono.Sugiyono (2014:409) memaparkan 10 langkah dalam penelitian dan pengembangannya, namun peneliti hanya menggunakan 9 diantaranya yang meliputi (1) potensi dan masalah, (2) pengumpulan data, (3) desain produk, (4) validasi desain, (5) revisi desain, (6) uji coba produk, (7) revisi produk, (8) uji coba pemakaian, dan (9) revisi produk. Adapun model pengembangan menurut Sugiyono (2014 : 409) adalah sebagai berikut :

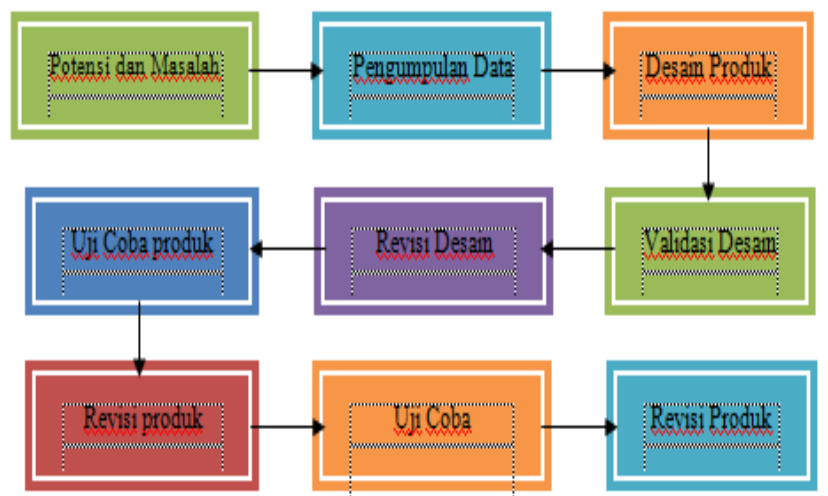

Gambar 1. Model Pengembangan Borg \& Gall dalam Sugiyono (Sugiyono, 2014 : 409)

\section{Jenis Data}

Sesuai dengan tujuan penelitian pengembangan ini, data yang dikumpulkan terdiri dari dua macam yaitu:

a. Kualitatif, yaitu data berupa masukan atau saran dari tim ahli dan mahasiswa pada saat uji coba produk baik uji coba terbatas maupun uji coba lapangan

b. Kuantitatif, yaitu data hasil angket tim ahli dan mahasiswa pada saat uji coba produk baik uji coba terbatas maupun uji coba lapangan

\section{Instrumen Pengumpulan Data}

Penelitian ini menggunakan instrumen pengumpulan data berupa lembar validasi LKS untuk uji kevalidan yaitu , 1) validasi ahli media , 2) validasi ahli materi dan 3) validasi ahli bahasa. Untuk uji coba kepraktisan berupa angket respon guru dan siswa sedangkan untuk uji coba keefektifan berupa tes uraian diakhir pembelajaran setelah menggunakan produk.

\section{Tehnik Analisis Data}

Data yang diperoleh dari penelitian ini dianalisis kemudian digunakan untuk merevisi LKS yang dikembangkan sehingga diperoleh LKS yang layak sesuai dengan kriteria yang ditentukan yaitu valid, praktis, dan efektif.

a. Analisis Kevalidan

Analisis data hasil validasi perangkat pembelajaran dilakukan dengan mencari ratarata penilaian validator terhadap masing-masing perangkat pembelajaran. Rumus yang digunakan sebagai berikut :

$\bar{X}=\frac{\sum_{i=1}^{n} \overline{A i}}{n}$

Keterangan :

$$
\begin{aligned}
& \bar{X}=\text { rata-rata } \\
& \overline{A i}=\text { rata-rata pemilihan validitas } \\
& n=\text { banyaknya item penilaian } \\
& \text { (Widoyoko, 2009: 238). }
\end{aligned}
$$

Untuk menentukan kategori kevalidan suatu perangkat diperoleh dengan mencocokkan ratarata $(\bar{X})$ dengan kategori kevalidan perangkat 
pembelajaran yang ditetapkan. Sedangkan interval ketagori ditentukan dengan rumus berikut:

Skor maksimum $\quad=5$

Skor minimum $=1$

Banyak Kategori $\quad=5$

Interval =

skormaksimum-skormin imum

banyaknya kategori

$$
\begin{aligned}
& =\frac{5-1}{5} \\
& =0,8
\end{aligned}
$$

Skala likert yang digunakan untuk penilaian para ahli adalah sama, maka interval kategori kevalidan produk baik validitas rata-rata setiap ahli maupun rata-rata total ahli adalah sama, sesuai Tabel 1 berikut :

TABEL 1

KATEGORI KEVALIDAN PRODUK

\begin{tabular}{|c|l|}
\hline Interval Skor & Kategori Kevalidan \\
\hline $1 \leq \bar{X}<1,8$ & Tidak Valid \\
\hline $1,8 \leq \bar{X}<2,6$ & Kurang Valid \\
\hline $2,6 \leq \bar{X}<3,4$ & Cukup Valid \\
\hline $3,4 \leq \bar{X} \leq 4,2$ & Valid \\
\hline $4,2 \leq \bar{X} \leq 5$ & Sangat Valid \\
\hline
\end{tabular}

(Widoyoko, 2009: 238)

Keterangan : $\bar{X}$ adalah rata-rata hasil penilaian validator terhadap pengembangan Lembar Kerja Siswa (LKS). Skor maksimal pada instrumen penilaian ahli materi, ahli media, ahli bahasa dan guru adalah 5 , sedangkan skor minimalnya yaitu 1.Perangkat dikatakan valid jika interval skor pada semua rata-rata berada pada kategori "Valid" atau "Sangat Valid". Sedangkan untuk mencari rata-rata tiap aspek dari semua validator menggunakan rumus :

$\overline{M_{v}}=\frac{\sum_{i=1}^{n} \overline{V_{i}}}{n}$

Keterangan :

$$
\begin{aligned}
& M_{v}=\text { rata-rata total validitas } \\
& \bar{V}_{i}=\text { rata-rata validasi validator ke-i } \\
& n=\text { banyaknya validator menurut } \\
& \text { (Sudijono, 2011: } 81 \text { ) }
\end{aligned}
$$

b. Analisis Kepraktisan Produk LKS

Penentuan kepraktisan perangkat pembelajaran dilihat dari konsistensi hasil penilaian praktisi terhadap guru yang menggunakan produk dan respon siswa dari pelaksanaan pembelajaran di kelas.

Analisis data ini dilakukan untuk mendeskripsikan penilaian guru terhadap proses pembelajaran dan penggunaan LKS dengan pendekatan problem solving yang telah dikembangkan. Data yang diperoleh dari angket penilaian guru yang disusun dengan interval 1 sampai 5. Memiliki skor 5 (sangat valid), skor 4 (valid), skor 3 (cukup valid), skor 2 (kurang valid), skor 1 (tidak valid) kemudian dihitung skor rata-ratanya. Setelah itu, hasilnya dikategorikan kedalam tabel kriteria angket penilaian guru.

TABEL 2.

KRITERIA ANGKET PENILAIAN GURU

\begin{tabular}{|l|l|}
\hline \multicolumn{1}{|c|}{ Rata-rata } & \multicolumn{1}{c|}{ Kategori } \\
\hline $1 \leq \bar{X}<1,8$ & Tidak Praktis \\
\hline $1,8 \leq \bar{X}<2,6$ & Kurang Praktis \\
\hline $2,6 \leq \bar{X}<3,4$ & Cukup Praktis \\
\hline $3,4 \leq \bar{X}<4,2$ & Praktis \\
\hline $4,2 \leq \bar{X} \leq 5$ & Sangat Praktis \\
\hline
\end{tabular}

(Widoyoko, 2009: 238)

Keterlaksanaan LKS berisi langkah-langkah yang harus dilakukan guru, skor yang harus diberikan pengamat berdasarkan petunjuk penilaian yang ada dan saran ahli. Keterlaksanaan langkah-langkah pembelajaran dikatakan baik jika persentase yang diperoleh $\geq$ 75\% (Trianto, 2011: 40).

Angket yang digunakan untuk mengumpulkan informasi tentang respon siswa terhadap kegiatan pembelajaran dan perangkat pembelajaran dengan menggunakan pendekatan problem solving bilangan pecahan. Siswa memberi tanda cek $(\sqrt{ })$ pada kolom yang tersedia untuk setiap pertanyaan yang diajukan. Angket tersebut diberikan kepada siswa pada akhir kegiatan pembelajaran. Data yang diperoleh berdasarkan angket tentang respon siswa terhadap kegiatan pembelajaran dan perangkat pembelajaran dianalisis dengan menggunakan analisis deskriptif yaitu dengan menghitung rata-rata dari tiap aspek respon siswa . Untuk menentukan kategori kepraktisan suatu diperoleh dengan mencocokkan rata-rata $(\bar{X})$ dengan kategori kevalidan perangkat pembelajaran yang ditetapkan. Sedangkan interval ketagori ditentukan dengan rumus berikut:

Skor maksimum $\quad=10$

Skor minimum $=0$

Banyak Kategori $\quad=5$

$$
\begin{aligned}
\text { Interval } & =\frac{\text { skormak }- \text { skor } \min }{\text { banyaknya kategori }} \\
& =\frac{10-0}{5} \\
& =2
\end{aligned}
$$

Skala likert yang digunakan untuk angket respon siswa adalah sama, maka interval kategori kepraktisan produk, sesuai Tabel 3 berikut : 
TABEL 3

KRITERIA ANGKET RESPON SISWA

\begin{tabular}{|l|l|}
\hline \multicolumn{1}{|c|}{ Rata-rata } & \multicolumn{1}{c|}{ Kategori } \\
\hline $0 \leq \bar{X}<2$ & Tidak Praktis \\
\hline $2 \leq \bar{X}<4$ & Kurang Praktis \\
\hline $4 \leq \bar{X}<6$ & Cukup Praktis \\
\hline $6 \leq \bar{X}<8$ & Praktis \\
\hline $8 \leq \bar{X} \leq 10$ & Sangat Praktis \\
\hline
\end{tabular}

Analisis respon siswa terhadap kegiatan pembelajaran dan perangkat pembelajaran dilakukan dengan mendeskripsikan respon siswa terhadap kegiatan pembelajaran dan perangkat pembelajaran. Angket respon siswa diberikan kepada siswa setelah seluruh kegiatan belajar mengajar selesai dilaksanakan. Reaksi siswa dikatakan positif jika $80 \%$ atau lebih siswa merespon dalam kategori positif (Triyanto, 2011: 243).

c. Analisis keefektifan perangkat pembelajaran Penentuan keefektifan perangkat pembelajaran matematika dengan menggunakan pendekatan problem solving dilihat dari pencapaian indikator dan aspek keefektifan yang ditetapkan berdasarkan ketuntasan hasil belajar siswa. Data diperoleh dari hasil tes tulis siswa yang diperiksa dan dinilai berdasarkan pedoman penskoran. Nilai maksimum untuk hasil belajar adalah 100. Hasil belajar dikatakan efektif atau tuntas secara individual jika mencapai kriteria ketuntasan minimal (KKM) yang ditetapkan sekolah yaitu 75, sedangkan keefektifan klasikal tercapai jika paling sedikit 75\% siswa subjek uji coba mencapai kriteria ketuntasan indivi dual.

Persentase ketuntasan klasikal dapat dihitung dengan menggunakan rumus sebagai berikut :

$$
\begin{aligned}
& \mathrm{KK}=\frac{S T}{J S} \times 100 \% \\
& \text { (Aqib, dkk., 2011: 41). }
\end{aligned}
$$

\section{HASIL DAN PEMBAHASAN}

Pada bagian ini akan dipaparkan tahapan-tahapan pada pengembangan LKS matematika dengan pendekatan Problem Solving. Adapun tahapantahapannya dijabarkan sebagai berikut.

\section{Tahap Potensi dan Masalah}

Potensi adalah segala sesuatu yang bila didayagunakan akan memiliki nilai tambah. Sedangkan masalah adalah penyimpangan antara apa yang diharapkan dengan apa yang terjadi. Masalah yang ada saat ini belum adanya pembelajaran yang menggunakan kuis interaktfi untuk melatih kemampuan eksplorasi.

Pada tahap ini dilakukan observasi pendahuluan di SMP Negeri 2 Praya dengan mengambil nilai ulangan harian siswa dan wawancara guru yang berisikan pertanyaan ketersediaan guru sumber, media pembelajaran, laboratorium matematika serta kemampuan guru dalam menggunakan media atau fasilitas-fasilitas tersebut. Hasil observasi tersebut kemudian dijadikan landasan dalam penyusunan latar belakang masalah dan gambaran dari analisis kebutuhan sekolah. Sehingga dibutuhkan media pembelajaran yang akan menambah nilai kebermanfaatan dari fasilitas tersebut, dapat memperjelas pesan, menimbulkan semangat belajar, dan memungkinkan anak belajar mandiri dengan masalah.

\section{Tahap Pengumpulan Data}

Setelah potensi dan masalah ditunjukkan secara factual, yang dilakukan selanjutnya adalah mengumpulkan informasi atau data yang dapat digunakan sebagai bahan untuk perencanaan produk yang diharapkan dapat mengatasi masalah. Pengumpulan informasi penelitian ini dilakukan di SMP Negeri 2 Praya dengan mewawancarai guru dan meminta hasil ulangan siswa sebagai landasan dalam penyusunan latar belakang.

\section{Tahap Desain Produk}

Desain produk ini diwujudkan dalam bentuk berupa kisi-kisi. Kisi-kisi adalah format pemetaan soal yang menggambarkan distribusi item berdasarkan jenjang kemampuan tertentu. Desain produk ini dilakukan untuk mengetahui tampilan awal atau rancangan produk yaitu kuesioner yang akan dikembangkan oleh peneliti. Pemilihan format dalam pengembangan perangkat pembelajaran meliputi isi materi adalah soal cerita aritmatika sosila, pendekatan pemebelajaran Problem Solving dengan media pembelajaran LKS dan RPP. Pada tahap ini dihasilkan perangkat pembelajaran yang meliputi RPP, LKS dan soal evaluasi. Serta penulisan instrument penelitian yang meliputi validasi RPP, lembar validasi LKS oleh ahli bahasa, angket penilaian guru terhadap perangkat dan proses pembelajaran serta angket respon siswa.

\section{Tahap Validasi Desain}

Validasi desain merupakan proses untuk menilai apakah rancangan desain produk sesuai dengan criteria pengembangan yang akan dibuat atau tidak. Desain produk awal divalidasi terlebih dahulu sebelum dilakukan uji coba. Validasi desain dilakukan oleh tiga tenaga ahli yaitu ahli media oleh Bapak Sirajudin, M.Pd, ahli materi oleh Ibu Vera Mandailina, M.Pd dan ahli bahasa oleh Bapak Drs. Akhmad H.Mus, M.Hum. Berikut ini hasil angket validator :

Pengujian produk oleh ahli materi ini dilakukan dengan menunjukkan dan menjelaskan tentang produk LKS berbasis Problem Solving kepada ahli media pembelajaran. Validator selaku Dosen Pendidikan Matematika di Universitas Muhammadiyah Mataram, Bapak Sirajudin,M.Pd. menurut validator LKS berbasis Problem Solving ini perlu diperbaiki di beberapa halaman yang telah dikoreksi yaitu dengan menambahkan ikon-ikon gambar kecil pada setiap lembaran dan membuat halaman LKS nya. 
Berdasarkan hasil angket ahli media di atas, maka diperoleh rata-rata dengan rumus sebagai berikut:

$$
\begin{aligned}
\bar{X} & =\frac{\sum_{i=1}^{n} \overline{A i}}{n} \\
& =\frac{4 \times 10+5 \times 10}{20} \\
& =\frac{90}{20} \\
= & 4,5
\end{aligned}
$$

Dapat dilihat nilai yang diberikan untuk kategori LKS rata-rata tiap aspek mendapat penlaian yang baik. Denga demiikian, berdasarkan kriteria kevalidan dapat dinyatakan bahwa LKS sudah termasuk dalam kategori "sangat valid". Perbaikan LKS berbasis Problem Solving ini juga memperhatikan pendapat dan saran yang diberikan oleh validator.

Pengujian produk oleh ahli materi ini dilkaukan dengan menunjukkan dan menjelaskan tentang produk LKS berbasis Problem Solving kepada ahli materi pembelajaran. Validator selaku Dosen Pendidikan Matematika Ibu Vera Mandailina, M.Pd memberikan penilaian terhadap LKS berbasis Problem Solving ini pada lembar validasi ahli materi. Saran beliau pada setiap contoh soal maupun tugasnya adalah menambahkan gambar yang menjelaskan tentang soal cerita tersebut supaya LKS terlihat lebih hidup lagi.

Berdasarkan hasil angket ahli materi, maka diperoleh ratra-rata dengan rumus sebagai berikut .

$$
\begin{aligned}
\bar{X} & =\frac{\sum_{i=1}^{n} \overline{A i}}{n} \\
& =\frac{3 \times 2+4 \times 13+5 \times 5}{20} \\
& =4,15
\end{aligned}
$$

Dapat dilihat nilai yang diberikan untuk kategori LKS rata-rata tiap aspek mendapat penlaian yang baik. Denga demiikian, berdasarkan kriteria kevalidan dapat dinyatakan bahwa LKS sudah termasuk dalam kategori "valid”. Perbaikan LKS berbasis Problem Solving ini juga memperhatikan pendapat dan saran yang diberikan oleh validator.

Pengujian produk oleh ahli bahasa ini dilkaukan dengan menunjukkan dan menjelaskan tentang produk LKS berbasis Problem Solving kepada ahli bahasa pembelajaran. Validator selaku Dosen Pendidikan Bahasa dan Sastra Indonesia di Universitas Muhammadiyah Mataram ,Bapak Drs. Akhmad H.Mus, M.Hum memberikan penalaian terhadap LKS berbasis Problem Solving ini pada lembar validasi ahli bahasa. Validator berpendapat bahwa LKS berbasis Problem Solving sudah bagus berdasarkan pemilihan jenis huruf dan bahasa yang digunakan sudah cukup baik. Tetapi saran dari validator perlu diperhatikan kata "adalah sebagai berikut” cukup hanya menggunakan kata "sebagai berikut" dengan diakhiri oleh tanda "titik" bukan "titik dua".

Berdasarkan hasil angket ahli materi, maka diperoleh rata-rata dengan rumus sebagai berikut :

$$
\begin{aligned}
\bar{X} & =\frac{\sum_{i=1}^{n} \overline{A i}}{n} \\
& =\frac{4 \times 5+5 \times 5}{10} \\
& =4,5
\end{aligned}
$$

Dengan demikian nilai yang diberikan berdasarkan criteria kevalidan, LKS sudah termasuk dalam kategori “sangat valid” .

Berdasarkan hasil validasi dari 3 dosen ahli tersebut maka diperoleh rata-rata validasi total dengan rumus sebagai berikut :

$$
\begin{aligned}
\bar{X} & =\frac{\sum_{i=1}^{n} \overline{A i}}{n} \\
& =\frac{4,5+4,15+4,5}{3} \\
& =4,4
\end{aligned}
$$

Nilai tersebut masuk dalam kategori "Sangat valid". Validasi ini dilakukan untuk mengetahui kelemahan dan kelebihan produk yang dikembangkan.

\section{SIMPULAN DAN SARAN}

\section{Kajian Produk yang Telah Direvisi}

Berdasarkan pembahasan hasil penelitian terhadap siswa kelas VII SMP Negeri 2 Praya, dapat disimpulkan bahwa LKS dan RPP yang dikembangkan termasuk dalam kategori valid, praktis dan efektif serta layak untuk digunakan. Pengembangan yang pembelajaran yang digunakan dalam penelitian ini adalah Borg And Gall dan produk yang dihasilkan yaitu berupa perangkat pembelajaran RPP dan LKS yang dirancang dengan pendekata Problem Solving.

\section{Saran}

a. LKS melalui dengan model pembelajaran Problem Solving ini sudah diuji kelayakannya dengan uji kevalidan, kepraktisan dan keefektifan maka disarankan kepada guru untuk menggunakan LKS ini sebagai alternatif bahan ajar dalam pembelajaran matematika pada materi aritmatika sosial.

b. LKS dengan model pembelajaran Problem Solving ini hanya terbatas pada materi Aritmatika Sosial, maka disarankan kepada peneliti selanjutnya untuk mengembangkannya pada materi pokok matematika yang lain dan objek penelitian yang berbeda.

c. Instrumen yang digunakan untuk menentukan kevalidan, kepraktisan dan keefektifan hanya terbatas lembar validasi ahli, lembar respon siswa dan tes hasil belajar siswa, sehingga 
terbuka peluang untuk peneliti lain untuk mengkaji lebih dalam untuk menggunakan instrumen yang lebih lengkap dengan menambahkan instrumen lain seperti lembar observasi aktivitas siswa, lembar keterlaksanaan pembelajaran, dan sebagainya.

\section{UCAPAN TERIMA KASIH}

Penulis mengucapkan terima kasih kepada Bapak Abdillah, M.Pd selaku Pembimbing 1 dan Bapak Syaharuddin, M.Si selaku Pembimbing 2 yang senantiasa memberikan bimbingan, nasehat, dan motivasi kepada penulis sehingga penelitian ini selesai dengan baik.

\section{DAFTAR RUJUKAN}

[1] Aqib, Zainal, dkk. 2011. Penelitian Tindakan Kelas untuk Guru SD, SLB, dan TK. Bandung. Yrama Widya, hal 41.

[2] Fadillah, M. 2014. Implementasi Kurikulum 2013 Dalam Pembelajaran SD/MI, SMP/MTS, dan SMA/MA. Yogyakarta: Ar-Ruzz.

[3] Hamdani. 2011. Strategi Belajar Mengajar. Bandung : Pustaka Setia.

[4] Hamiyah, Jauhar. 2014. Strategi Belajar Mengajar di Kelas. Jakarta : Prestasi Pustaka.

[5] Kusnaedi,dkk. 2013. Kurikulum 2013 Mata Pelajaran Matematika Sekolah Menengah Tingkat Pertama dan Madrasah Tsanawiyah. Jakarta: Kemendikbud, hal 221.

[6] Novaztiar,Limbar. 2016. Penerapan Metode Pemecahan Masalah (Problem Solving) pada Mata Pelajaran Matematika Kelas IV di MI Ma'Aruf. Skripsi. Institut Agama Islam Negeri Purwokerto. Purwokerto.

[7] Nugroho, Nanang Budi. 2014. Pengembangan RPP dan LKS berbasis Problem Based Learning pada Materi Himpunan. Skripsi. Universitas Negeri Yogyakarta. Yogyakarta..

[8] Prastowo, Andi. 2015. Panduan Kreatif Membuat Bahan Ajar Inovatif. Yogyakarta : Diva Press, hal 204.

[9] Sanjaya, Wina. 2009. Strategi Pembelajaran Berorientasi Standar Proses Pendidikan. Prenada : Jakarta, hal 220.

[10] Sanjaya, 2011. Perencanaan dan Desain Sistem Pembelajaran. Jakarta : Kencana.

[11] Sudijono, Anas. 2011. Pengantar Statistik Pendidikan. Jakarta: Raja Grafindo Persada.

[12] Sugiyono. 2015. Metode Penelitian Pendidikan Pendekatan Kuantitatif, Kualitatif, dan R\&D. Bandung : Alfabeta.

[13] Syarifudin. 2010. Jurnalistik Terapan. Bogor : Ghalia Indonesia. Hal 150

[14] Triyanto. 2011. Mendesain Model Pembelajaran InovatifProgresif : Konsep Landasan, Implementasi pada Kurikulum Tingkat Satuan Pendidikan (Ktsp). Jakarta : Kencana, hal 243.

[15] Mandailina, Vera. 2011. Eksperimental Strategi Pembelajaran Matematika Berbasis Masalah (Problem Solving) Dan Kontekstual ( Cotextual Teaching And Learning) Ditinjau Dari Gaya Belajar Siswa di Kota Surakarta. Thesis. Universitas Sebelas Maret Surakarta. Surakarta.

\section{PROFIL PENULIS UTAMA}

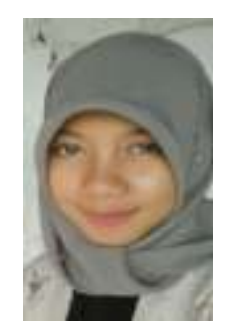

Penulis bernama lengkap“Anggita Denia".Lahir di Kota Praya Kab. Lombok Tengah pada tanggal 04 Desember 1994 dari pasangan Jordan Martha dan Husniah. Penulis adalah anak pertama dari 3 bersaudara. Pendidikan sekolah dasar di mulai dari SDN Impres Serengat Kota Praya 2000 - 2006. Setelah itu melanjutkan pendidikan sekolah menengah ke SMPN 2 Praya padatahun 2007 - 2009 dan terakhir di SMAN 2 Praya pada tahun 2010 - 2013. Kemudian penulis melanjutkan studi keperguruan tinggi di Program Studi Pendidikan Matematika FKIP UM Mataram pada tahun 2013. Kritik, saran, maupun hal-hal yang berkaitan dengan kelanjutan atau pengembangan dari hasil penelitian ini bias dikirim ke email penulisdi : anggitadhenia@gmail.com 